\title{
Peningkatan Kompetensi Profesional Guru melalui Penelitian Tindakan Kelas
}

\author{
Muhammad Nafi Annury \\ Universitas Islam Negeri Walisongo Semarang \\ Email: nafi.annury@walisongo.ac.id
}

\begin{abstract}
This paper evokes efforts to increase teacher competency in the madrasa through classroom action research. In delivering knowledge, not only can it be done in the classroom, but it can also be done outside the classroom. Scientific work is also a professional value of a teacher, because the activity of writing scientific work supports the teaching profession, both in the learning and teaching process or in discussing to solve certain problems proposed. The problems identified in this community service program are: the teachers' knowledge and understanding of Classroom Action Research is still lacking, the teacher's experience in classroom action research is still lacking, the experience of preparing proposals is still lacking, and culture in research activities in the school environment is still lacking. The results obtained through this activity are there is an increase in the understanding of subject teachers in the implementation of Classroom Action Research, an increase in the ability of subject teachers in preparing proposals for Classroom Action Research at SMPIT Assalamah Ungaran and an increase in the ability of subject teachers in conducting Classroom Action Research.
\end{abstract}

Abstrak: Tulisan ini mengunkap upaya peningkatan kompetensi guru di madrasah melalui penelitian tindakan kelas. Karya tulis ilmiah tidak hanya dapat dinikmati oleh peserta didik, tetapi juga oleh masyarakat luas. Karya ilmiah juga merupakan nilai profesionalisme dari seorang guru, karena kegiatan menulis karya ilmiah mendukung profesi guru, baik dalam proses belajar dan mengajar ataupun dalam berdiskusi untuk memecahkan masalah tertentu yang diajukan. Permasalahan yang diidentifkasi pada program pengabdian kepada masyarakat ini adalah: pengetahuan dan pemahaman para guru tentang Penelitian Tindakan Kelas masih kurang, pengalaman guru dalam hal penelitian tindakan kelas masih kurang, pengalaman menyusun proposal masih kurang, dan budaya dalam hal kegiatan penelitian di lingkungan sekolah masih kurang. Hasil yang diperoleh melalui kegiatan ini yaitu terdapat peningkatan pemahaman para guru mapel disekolah dalam pelaksanaan Penelitian Tindakan Kelas, peningkatan kemampuan para guru mapel dalam menyusun proposal Penelitian Tindakan Kelas di SMPIT Assalamah Ungaran dan terdapat peningkatan kemampuan para guru mapel dalam melaksanakan Penelitian Tindakan Kelas.

Kata Kunci: Kompetansi, guru, tindakan kelas. 


\section{PENDAHULUAN}

Badegan Pendidikan merupakan faktor utama dalam pembentukkan pribadi manusia. Pendidikan sangat berperan dalam membentuk baik atau buruknya pribadi manusia menurut ukuran normatif. Menyadari akan hal tersebut, pemerintah sangat serius menangani bidang pendidikan, sebab dengan sistem pendidikan yang baik diharapkan muncul generasi enerus bangsa yang berkualitas dan mampu menyesuaikan diri untuk hidup ermasyarakat, berbangsa dan bernegara. Reformasi pendidikan merupakan respon terhadap perkembangan tuntutan global sebagai suatu upaya untuk mengadaptasikan sistem pendidikan yang mampu mengembangkan sumber daya manusia untuk memenuhi tuntutan zaman yang sedang berkembang. Melalui reformasi pendidikan, pendidikan harus berwawasan masa depan yang memberikan jaminan bagi perwujudan hak-hak azasi manusia untuk mengembangkan seluruh potensi dan prestasinya secara optimal guna kesejahteraan hidup di masa depan.

Pada dasarnya sekolah merupakan wahana proses belajar mengajar yang paling pokok, dan juga sebagai proses tingkah laku ditimbulkannya melalui latihan atau pengalaman. Dalam proses belajar ini seseorang berinteraksi langsung dengan objek belajar dengan menggunakan alat inderanya. Karena itu pentingnya pendidikan, maka bagian terbesar upaya riset dan eksperimen serta pendidikan diarahkan pada tercapainya pemahaman yang lebih luas dan mendalam mengenai proses perubahan.

Guru adalah salah satu unsur manusia dalam proses pendidikan. Dalam proses pendidikan di sekolah, guru memegang tugas ganda yaitu sebagai pengajar dan pendidik. Sebagai pengajar guru bertugas menuangkan sejumlah bahan pelajaran ke dalam otak anak didik, sedangkan sebagai pendidik guru bertugas membimbing dan membina anak didik agar menjadi manusia susila yang cakap, aktif, kreatif, dan mandiri. Djamarah berpendapat bahwa baik mengajar maupun mendidik merupakan tugas dan tanggung jawab guru sebagai tenaga profesional agar menjadi manusia susila yang cakap, aktif, kreatif, dan mandiri. Djamarah berpendapat bahwa baik mengajar maupun mendidik merupakan tugas dan tanggung jawab guru sebagai tenaga profesional. Oleh sebab itu, tugas yang berat dari seorang guru ini pada dasarnya hanya dapat dilaksanakan oleh guru yang memiliki kompetensi profesional yang tinggi.

Guru memegang peranan sentral dalam proses belajar mengajar, untuk itu mutu pendidikan di suatu sekolah sangat ditentukan oleh kemampuan yang dimiliki seorang guru dalam menjalankan tugasnya. 
Pada dasarnya tingkat kompetensi profesional guru dipengaruhi oleh faktor dari dalam guru itu sendiri yaitu bagaimana guru bersikap terhadap pekerjaan yang diemban. Sedangkan faktor luar yang diprediksi berpengaruh terhadap kompetensi profesional seorang guru yaitu kepemimpinan kepala sekolah, karena kepala sekolah merupakan pemimpin guru di sekolah. Kompetensi profesional guru dapat tercermin dari keberhasilan proses belajar mengajar disuatu kelas. Disamping itu keberhasilan pengajaran dikelas dapat pula dilihat dari meningkatnya prestasi akademik siswa dikelas.

Mengajar adalah menyampaikan pengetahuan pada anak didik, ini berarti tujuan belajar siswa itu hanya sekedar ingin mendapatkan pengetahuan sebagai konsekuensi pengertian semacam ini dapat membuat suatu kecenderungan nak menjadi pasif karena hanya menerima informasi atau pengetahuan yang diberikan oleh gurunya. Jadi gurulah yang memegang kunci dalam proses belajar mengajar di kelas.

Pada dasarnya kegiatan belajar mengajar apabila ada seseorang siswa, misalnya tidak berbuat sesuatu yang seharusnya dikerjakan maka perlu diselidiki sebab-sebabnya. Sebab-sebabnya itu biasanya bermacam-macam, mungkin ia tidak senang sakit, lapar ada problem pribadi dan lain-lain. Hal ini berarti pada diri anak tidak terjadi perubahan energi, tidak terangsang afeksinya untuk melakukan sesuatu, karena tidak memiliki tujuan atau kebutuhan belajar.

Siswa dapat dengan mudah menyerap informasi yang disampaikan guru, siswa merasa nyaman belajar dikelas, serta pembelajaran yang aktif, kreatif serta menyenangkan adalah beberapa contoh bahwa guru telah sukses dalam menerapkan KBM dikelas.

Dalam rangka mencapai tujuan pembelajaran yang bermutu maka alangkah baiknya guru harus menrapkan metode pembelajaran yang mampu meningkatkan prestasi siswa pada proses KBM dikelas. Dalam hal ini guru dapat menerapkan metode penelitian tindakan kelas. Diharapkan dengan penerapan penelitian tindakan kelas yang disingkat (PTK) ini guru dapat melakukan evaluai terhadap kemajuan KBM nya selama satu semester. Bahwa pendidikan merupakan hal yang penting dalam kehidupan manusia kiranya merupakan hal yang tak terbantahkan. Pada kenyataannya pendidikan telah dilaksanakan semenjak adanya manusia, hakikatnya pendidikan merupakan serangkaian peristiwa yang kompleks yang melibatkan beberapa komponen antara lain: tujuan, pendidik, peserta didik, isi/bahan, cara/metode dan situasi/lingkungan. Hubungan keenam faktor tersebut berkaitan satu sama lain dan saling berhubungan dalam suatu aktifitas suatu pendidikan (Hadikusumo, 1995). 
Berdasarkan pengamatan yang dilakukan oleh peneliti di SMPIT Assalamah Ungaran dapat ditentukan hal sebagai berikut: 1) Kondisi lingkungan yang kurang kondusif karena letak sekolahan yang berdekatan dengan jalan raya. 2) berdekatan dengan pasar. Dari sitausi dan kondisi seperti ini mempengaruhi proses belajar mengjar yang sedang berlangsung seperti kebisingan dari arah jalan raya, sehingga perhatian siswa dapat terganggu. Selain itu perhatian orang tua terhadap prestasi belajar anaknya yang sangat menurun, banyak orang tua yang bersikap masa bodoh ini menyebakan turunnya prestasi belajar.

Alam kegiatan belajar mengajar apabila ada seseorang siswa, misalnya tidak berbuat sesuatu yang seharusnya dikerjakan maka perlu diselidiki sebabsebabnya. Sebab-sebabnya itu biasanya bermacam-macam, mungkin ia tidak senang sakit, lapar ada problem pribadi dan lain-lain. Hal ini berarti pada diri anak tidak terjadi perubahan energi, tidak terangsang afeksinya untuk melakukan sesuatu, karena tidak memiliki tujuan atau kebutuhan belajar.

Salah satu hal yang dapat dilakukan guru yaitu dengan melakukan penelitian tindakan kelas. Hal ini perlu dapat dilakukan sebagai bentuk tanggung jawab guru terhadap murid muridnya didalam kelas serta melaksanakan kewajiban profesional mereka sesuai dengan undang undang guru dan dosen tahun 2014. Dengan melaksanakan penelitian tindakan kelas tersebut diharapkan guru banyak kunci keberhasilan dalam misi pendidikan dan pembelajaran di sekolah selain bertanggung jawab untuk mengatur, mengarahkan dan menciptakan suasana kondusif yang mendorong siswa untuk melaksanakan kegiatan di kelas.

Banyak metode mengajar yang dapat ditetapkan dalam proses KBM salah satunya di antaranya adalah dengan metode cerita, ceramah, role play dst. Dengan berbagai metode pengajaran ini diharapkan anak dapat menggali dan menemukan inti-inti materi melalui potongan kertas sehingga anak merasa senang dan materi yang dipelajari melekat dalam benaknya.

\section{METODE PENGABDIAN KEPADA MASYARAKAT}

Media Khalayak sasaran yang dituju dari kegiatan ini adalah guru-guru mapel yang tergabung dalam MGMP Kab. Semarang baik negeri maupun swasta di wilayah Kota Semarang. Khalayak sasaran yang dilibatkan dalam kegiatan pengabdian kepada masyarakat ini adalah guru mapel di Kab. Semarang. Penentuan sasaran kegiatan tersebut didasarkan pada banyaknya guru di SMPIT Assalamah Ungaran Kab. Semarang yang mengajarkan semua mapel, juga dengan mempertimbangkan bahwa guru SMPIT Assalamah Kab. Semarang merupakan salah satu yayasan pendidikan yang maju di Kab. Semarang. Tetapi, kenyataannya sebagian besar guru bahasa Jepang kurang masih memiliki 
kemampuan memadai mengenai penelitian tindakan. Kegiatan ini diharapkan mampu membantu mereka yang belum mendapatkan kesempatan mengikuti kegiatan semacam ini untuk meningkatkan pengetahuan dan kemampuan melaksanakan penelitian tindakan kelas sehingga dapat lebih meningkatkan kualitas profesionalisme guru-guru mapel di SMPIT Assalamah Ungaran. Agar pelaksanaan kegiatan ini bisa berlangsung dengan efektif maka peserta yang dilibatkan sejumlah 30 orang. Mereka yang mengikuti kegiatan ini diharapkan selanjutnya akan menyebarluaskan pengetahuan dan kemampuan yang diperolehnya kepada guru mapel yang lain.

Metode yang dilakukan dalam kegiatan ini adalah pelatihan. Metode ini dipilih untuk memberi kesempatan kepada guru-guru agar bisa mengalami sendiri langkah demi langkahproses penyusunan peoposal penelitian tindakan kelas sesuai dengan permasalahanpembelajaran yang dihadapi oleh para guru dalam belajar mengajar di sekolahmasing-masing. Dalam pelatihan ini, pada awalnya, para guru diberi kesempatan untuk mendengarkan ceramah dan melakukan Tanya jawab tentang penelitian tindakan kelas dan penyusunan proposal. Langkah selanjutnya, mereka diberi kesempatan untuk menyusun sebuah proposal penelitian tindakan kelas berdasarkan kebutuhan dan permasalahan yang mereka hadapi masing-masing. Dengan demikian, guru-guru dapat menafsirkan, memaknai dan menarik simpulan sendiri tindakan perbaikan pembelajaran yang diambil. Dengan metode pelatihan, guru-guru memperoleh pengetahuan mengenai penelitian tindakan kelas dan penyusunan proposal, sekaligus mempraktekkan penyusunan proposal, dan pelaksanaan penelitian tindakan kelas. Materi pelatihan meliputi (a) Jenis-jenis penelitian pendidikan, (b) Pengertian dan karakteristik PTK (c) Penyusunan proposal PTK (d) Pelaksanaan PTK, (e) Penyusunan Laporan PTK, 3. Menyediakan buku pedoman PTK yang meliputi penyusunan proposal, dan pelaksanaannya. Menyediakan contoh proposal PTK, dan setiap materi pelatihan dibuat hand out agar memudahkan peserta dalam memahami materi. 4. Setiap peserta diwajibkan untuk menyusun satu proposal PTK agar dapat dipantau sejauh mana pemahamannya tentang PTK.

\section{REVIEW KEPUSTAKAAN}

Menurut Penelitian tindakan berasal dari istilah bahasa Inggris action research. Ini merupakan perkembangan baru dalam penelitian, yang muncul sejak tahun 1940-an. Mulanya penelitian tindakan diterapkan dalam penelitian sosial, seorang psikolog sosial Kurt Lewin (1946) mengembangkaknnya dan kemudian 
diadopsi dalam kancah pendidikan (Syamsuddin, 2007 : 1991). Istilah educational action research dipakai oleh Kemmis untuk jenis penelitian tindakan pendidikan (Rochiati, 2008 : 4). Di Indonesia penelitian tindakan kelas mulai digerakkan sejalan dengan upaya peningkatan mutu pendidikan diusahakan oleh berbagai kalangan baik pemerintah maupun masyarakat. Berbagai perguruan tinggi seperti IKIP Jakarta, Bandung, Malang dan lain-lain melalui Program Pascasarjananya mengenalkan peneltitian tindakan kelas ini kepada guru-guru yang sedang melanjutkan studi.

Beberapa ahli mengemukakan pendapat tentang penelitian tindakan, Kemmis (1983) misalnya menyatakan bahwa penelitian tindakan merupakan upaya mengujicobakan ide-ide ke dalam praktek untuk memperbaiki atau mengubah sesuatu agar memperoleh dampak nyata dari situasi (Syamsuddin, 2007 : 1991). Selanjutnya Kemmis dan Taggart (1985) menyatakan bahwa penelitian tindakan adalah suatu bentuk penelitian reflektif yang secara kolektif dilakukan peneliti dalam situasi sosial untuk meningkatkan penalaran dan keadilan praktek pendidikan dan sosial serta dalam mengorganisasi suatu kondisi sehingga mereka dapat memahami pengalaman mereka serta memahami bagaimana mempraktekan ini di lingkungan kerja mereka. Dengan kata lain penelitian tindakan adalah cara suatu kelompok atau seseorang dalam mengorganisir suatu kondisi sehingga mereka dapat mempelajari pengalaman dan membuat pengalaman mereka dapat diakses oleh orang lain.

Sementara yang dimaksud dengan penelitian tindakan kelas adalah penelitian yang dilakukan oleh guru di kelasnya sendiri dengan jalan merencanakan, melaksanakan, dan merefleksikan tindakan secara kolaboratif dan partisipatif dengan tujuan untuk memperbaiki kinerjanya sebagai guru sehingga hasil belajar siswa dapat meningkat. Dengan demikian penelitian tindakan kelas merupakan suatu pencermatan terhadap kegiatan belajar berupa sebuah tindakan, yang sengaja dimunculkan dan terjadi dalam sebuah kelas secara bersama. Tindakan tersebut diberikan oleh seorang guru atau dengan arahan dari guru yang dilakukan oleh siswa (Suharsimi, 2008 : 3-4) . Penelitian tindakan kelas dikakukan untuk beberapa hal; Meningkatkan kualitas pendidikan, Memperbaiki kualitas proses pembelajaran (Mc Niff, 1992), pengembangan ketrampilan guru bertolak dari kebutuhan dalam memecahkan problem yang dihadapi di kelas (Borg, 1986). dan menumbuhkan budaya meneliti di kalangan guru yang disertai mekanisme koreksi diri dari guru (built in self-correcting mechanism) untuk meningkatkan profesionalisme guru.

Fungsi Penelitian Tindakan sebagaimana yang dikemukakan oleh Cohen dan Manion (1980) sebagaimana dikutip Syamsuddin, 2007 : 200 adalah: 
1. Sebagai alat untuk memecahkan masalah yang dilakukan dengan cara diagnosis dalam situasi tertentu.

2. Sebagai alat dalam pelatiahan jabatan

3. Sebagai alat untuk mengenalkan pendekatan tambahan atau inovatif dalam pengajaran.

4. Sebagai alat untuk meningkatkan komunikasi antar guru di lapangan dan peneliti akademis.

Penelitian tindakan kelas apabila dilakukan dengan baik oleh guru akan menghasilkan manfaat bagi:

1. Terwujudnya inovasi pembelajaran

2. Pengembangan kurikulum di tingkat sekolah dan di tingkat kelas.

3. Peningkatan profesionalisme guru

Mengacu pada Suharsimi Arikunto dkk. (2008: 6-12), prinsip penelitian tindakan kelas dapat dijelaskan sebagai berikut. Pertama, Kegiatan nyata dalam situasi rutin. PTK dilakukan oleh peneliti tanpa mengubah situasi rutin dengan harapan bahwa peneliti akan mendapatkan data dalam situasi wajar sehingga hasil PTK dapat dimanfaatkan untuk meningkatkan proses belajar mengajar.

Kedua, Adanya kesadaran diri untuk memperbaiki kinerja. Pada dasarnya manusia bukanlah makhluk yang statis, akan tetapi ada keinginan pada tiap diri manusia untuk menginginkan sesuatu yang lebih baik. PTK dilakukan oleh seorang guru bukan dalam konteks keterpaksaan atau permintaan dari pihak lain akan tetapi atas kesadaran dan inisiatif guru untuk meningkatkan kualitas pembelajaran yang akan berdampak pada peningkatan kualitas peserta didik.

Ketiga, SWOT (strength: kekuatan, weakness: kelemahan, opportunity: kesempatan, threat: ancaman) sebagai dasar berpijak. Kekuatan dan kelemahan yang ada pada diri peneliti dan subyek tindak diidentifikasi secara cermat. Dua unsur lain, yaitu kesempatan dan ancaman diidentifikasi dari pihak yang ada di luar diri guru atau peneliti dan juga di luar diri siswa atau subyek yang dikenai tindakan.

Keempat, Upaya empiris dan sistemik. Prinsip keempat ini merupakan penreapan dari prinsip ketiga. Kelima, Prinsip SMART; Spesifik - khusus, tidak terlalu umum, Managable - dapat dikelola, dilaksanakan, Acceptable - dapat diterima lingkungan atau Achievable - dapat dicapai Realistic - operasional, tidak di luar jangkauan; dan Time-bound - diikat oleh waktu, terencana.

Sedangkan menurut Sukidin, dkk (2002: 19-21), prinsip-prinsip dari penelitian tindakan kelas ada enam; metode PTK yang akan diterapkan tidak akan mengganggu komitmennya sebagai pengajar, Metode pengumpulan data 
yang akan digunakan tidak menuntut waktu yang berlebihan dari guru sehingga berpeluang mengganggu proses pembelajaran. Dengan kata lain, guru mampu menangani prosedur pengumpulan data dan ia tetap aktif berfungsi sebagai guru yang bertugas secara penuh. Metodologi yang digunakan harus reliable. Masalah penelitian yang diusahakan oleh guru seharusnya merupakan masalah yang cukup merisaukannya. Dalam melaksanakan PTK, guru harus selalu bersikap konsisten menaruh kepedulian tinggi terhadap prosedur etika yang berkaitan dengan pekerjaannya. Dan Permasalahan tidak dilihat terbatas dalam konteks dalam kelas atau mata pelajaan tertentu, melainkan dalam perspektif misi sekolah secara keseluruhan.

Penelitian Tindakan Kelas adalah penelitian praktis yang dimaksudkan untuk memperbaiki pembelajaran di kelas. Penelitian ini merupakan salah satu upaya guru atau praktisi dalam bentuk berbagai kegiatan yang dilakukan untuk memperbaiki dan atau meningkatkan mutu pembelajaran di kelas. Pengertian Penelitian Tindakan Kelas (PTK) berkembang dari istilah penelitian tindakan (action research) (Sanjaya, hal. 24). Oleh karena itu, untuk memahami pengertian PTK perlu ditelusuri pengertian penelitian tindakan terlebih dahulu. Penelitian tindakan mulai berkembang di Amerika dan berbagai negara di Eropa, khususnya dikembangkan oleh mereka yang bergerak di bidang ilmu sosial dan humaniora (Basrowi \& Suwandi, hal. 24-25).

Orang-orang yang bergerak di bidang itu dituntut untuk terjun mempraktikkan suatu tindakan atau perlakuan di lapangan. Mereka berarti langsung mempraktikkan tindakan yang telah direncanakan dan mengukur kelayakan tindakan yang diberikan tersebut. Menurut Kemmis (1988), penelitian tindakan adalah suatu bentuk penelitian reflektif dan kolektif yang dilakukan peneliti dalam situasi sosial untuk meningkatkan penalaran praktik sosial mereka (Sanjaya, hal. 24). Dalam hal ini, penelitian tindakan memiliki kawasan yang lebih luas daripada PTK. Penelitian tindakan diterapkan di berbagai bidang ilmu di luar pendidikan, misalnya dalam kegiatan praktik bidang kedokteran, manajemen, dan industri (Basrowi \& Suwandi, hal. 25). Bila penelitian tindakan yang berkaitan pada bidang pendidikan dilaksanakan dalam kawasan sebuah kelas, maka penelitian tindakan tindakan ini disebut PTK.

Penelitian Tindakan Kelas berasal dari bahasa Inggris, yaitu Classrom Action Research, diartikan penelitian dengan tindakan yang dilakukan dikelas. Menurut John Elliot, PTK adalah peristiwa sosial dengan tujuan untuk meningkatkan kualiatas tindakan di dalamnya. Di mana dalam proses tersebut mencakup kegiatan yang menimbulkan hubungan antara evaluasi diri dengan peningkatan profesional. Menurut Kemmis dan Mc. Taggart (Sanjaya,2010:25), PTK 
adalah gerakan diri sepenuhnya yang dilakukan oleh peserta didik untuk meningkatkan pemahaman. Menurut Arikunto (Suyadi,2012:18), PTK adalah gabungan pengertian dari kata "penelitian, tindakan dan kelas". Penelitian adalah kegiatan mengamati suatu objek, dengan menggunakan kaidah metodologi tertentu untuk mendapatkan data yang bermanfaat bagi peneliti dan dan orang lain demi kepentingan bersama. Selanjutnya tindakan adalah suatu perlakuan yang sengaja diterapkan kepada objek dengan tujuan tertentu yang dalam penerapannya dirangkai menjadi beberapa periode atau siklus. Dan kelas adalah tempat di mana sekolompok siswa belajar bersama dari seorang guru yang sama dalam periode yang sama.

Berdasarkan beberapa pemahaman mengenai PTK diatas dapat disimpulkan bahwa penelitian tindakan kelas (PTK) adalah suatu pengamatan yang menerapkan tindakan didalam kelas dengan menggunakan aturan sesuai dengan metodologi penelitian yang dilakukan dalam beberapa periode atau siklus. Berdasarkan jumlah dan sifat perilaku para anggotanya, PTK dapat berbentuk individual dan kaloboratif, yang dapat disebut PTK individual dan PTK kaloboratif. Dalam PTK individual seorang guru melaksanakan PTK di kelasnya sendiri atau kelas orang lain, sedang dalam PTK kaloboratif beberapa orang guru secara sinergis melaksanakan PTK di kelas masing-masing dan diantara anggota melakukan kunjungan antar kelas.

Berdasarkan pada pengertian di atas, PTK memiliki karakterlistik tersendiri sebagai pembeda dengan penelitian-penelitian lainya. Adapun beberapa karakter tersebut meliputi; PTK hanya dilakukan oleh guru yang memahami bahwa proses pembelajaran perlu diperbaiki dan ia terpanggil jiwanya untuk memberikan tindakan-tindakan tertentu untuk membenahi masalah dalam proses pembelajaran dengan cara melakukan kolaborasi. Refleksi diri, refleksi merupakan salah satu ciri khas PTK yang paling esensial. Dan ini sekaligus sebagai pembeda PTK dengan penelitian lainnya yang menggunakan responden dalam mengumpulkan data, sementara dalam PTK pengumpulan data dilakukan dengan refleksi diri. (Tahir, 2012:80). Penelitian tindakan kelas dilaksanakan di dalam "kelas" sehingga interaksi antara siswa dengan guru dapat terfokuskan secara maksimal. "Kelas" yang dimaksud di sini bukan hanya ruang yang berupa gedung, melainkan "tempat" berlangsungnya proses pembelajaran antara guru dan murid. (Suyadi,2012:6). PTK bertujuan untuk memperbaiki proses pembelajaran secara terus menerus. PTK dilaksakan secara berkesinambungan di mana setiap siklus mencerminkan peningkatan atau perbaikan. Dan PTK merupakan salah satu indikator dalam peningkatan profesionalisme guru, karena PTK memberi motivasi kepada guru untuk berfikir Kritis dan sistematis, 
membiasakan guru untuk menulis, dan membuat catatan yang dapat. Di mana semua itu dapat menunjang kemampuan guru dalam pembelajaran. (Daryanto,2011:6).

Menurut Sukardi (2008:211-212), karakteristik penelitian tindakan antara lain; Problem yang dipecahkan merupakan persoalan praktis yang dihadapi peneliti dalam kehidupan profesi sehari-hari. Peneliti memberikan perlakuan atau treatment berupa tindakan yang terencana untuk memecahkan permasalahan dan sekaligus meningkatkan kualitas yang dapat dirasakan implikasinya oleh subyek yang diteliti. Langkah-langkah penelitian yang direncanakan selalu dalam bentuk siklus, tingkatan atau daur yang memungkinkan terjadinya kerja kelompok maupun kerja mandiri secara intensif. Dan Adanya langkah berpikir reflektif atau reflective thinking dari peneliti baik sesudah maupun sebelum tindakan.

Sedangkan menurut Priyono dalam makalahnya berjudul "Action Research sebagai Strategi Pengembangan Profesi Guru” (1999), karakteristik penelitian tindakan kelas adalah sebagi berikut: Masalah yang dijadikan obyek penelitian muncul dari dunia kerja peneliti. Bertujuan memecahkan masalah untuk meningkatkan kualitas. Menggunakan data yang beragam. Langkah-langkahnya merupakan siklus. Dan Mengutamakan kerja kelompok.

Tabel 1

Perbedaan Antara Penelitian Tindakan Kelas dengan Penelitian Formal Lainnya

\begin{tabular}{|c|c|c|}
\hline Dimensi & PTK & Penelitian Formal \\
\hline Motivasi & Melakukan tindakan & Mencari kebenaran \\
\hline Sumber masalah & Diagnosis of status & Induction-deduction \\
\hline Tujuan & Mempraktekkan & $\begin{array}{l}\text { Memverifikasi dan } \\
\text { menemukan pengetahuan } \\
\text { umum }\end{array}$ \\
\hline Keterlibatan peneliti & $\begin{array}{l}\text { Guru/dosen, peneliti dari } \\
\text { dalam }\end{array}$ & $\begin{array}{l}\text { Peneliti dari luar, } \\
\text { pengamat }\end{array}$ \\
\hline Sampel & Kasus tertentu & Representative sample \\
\hline Metodologi & $\begin{array}{l}\text { Bebas tapi tetap menjaga } \\
\text { objektifitas }\end{array}$ & Mengikuti kaidah baku \\
\hline Interpretasi temuan & $\begin{array}{l}\text { untuk memahami praktek } \\
\text { tindakan melalui refleksi } \\
\text { teori para praktisi }\end{array}$ & $\begin{array}{l}\text { untuk menjelaskan dan } \\
\text { membangun teori yang } \\
\text { dilakukan para ilmuwan }\end{array}$ \\
\hline
\end{tabular}


Hasil akhir

Proses pembalajaran yang Pengetahuan yang teruji

lebih baik

\section{Prosedur Penelitian Tindakan Kelas}

Seseorang yang berkehendak melaksanakan suatu penelitian baik berupa penelitian positivisme, naturalistik, analisis isi maupun PTK selalu mengawali dengan gagasan - gagasan atau ide - ide, dan gagasan itu dimungkinkan yang dapat dikerjakan atau dilaksanakannya. Pada umumnya ide awal yang menggayut di PTK ialah terdapatnya suatu permasalahan yang berlangsung di dalam suatu kelas. Ide awal tersebut di antaranya berupa suatu upaya yang dapat ditempuh untuk mengatasi permasalahan. Penerapan PTK berarti peneliti mau berbuat sesuatu demi terciptanya suatu perubahan dan perbaikan di dalam kelas.

Pra-survei dimaksudkan untuk mengetahui secara detail kondisi yang terdapat di suatu kelas yang akan diteliti. Bagi pengajar yang bermaksud melakukan penelitian di kelas yang menjadi tanggung jawabnya tidak perlu melakukan pra-survai karena berdasarkan pengalamannya selama dia di depan kelas sudah secara cermat dan pasti mengetahui berbagai permasalahan yang dihadapinya, baik yang berkaitan dengan kemajuan siswa, sarana pengajaran maupun sikap siswanya. Dengan demikian para guru yang sekaligus sebagai peneliti di kelasnya sudah akan mengetahui kondisi kelas yang sebenarnya.

Diagnosis dilakukan oleh peneliti yang tidak terbiasa mengajar di suatu kelas yang dijadikan sasaran penelitian. Peneliti dari luar lingkungan kelas/sekolah perlu melakukan diagnosa atau dugaan-dugaan sementara mengenai timbulnya suatu permasalahan yang muncul di dalam satu kelas. Dengan diperolehnya hasil diagnosis, peneliti PTK akan dapat menentukan berbagai hal, misalnya strategi pengajaran, media pengajaran, dan materi pengajaran yang tepat dalam kaitannya dengan implementasi PTK.

Perencanaan dalam PTK dapat dipisahkan menjadi dua, yaitu perencanaan umum dan perencanaan khusus. Perencanaan umum dimaksudkan untuk menyusun rancangan yang meliputi keseluruhan aspek yang terkait PTK. Sementara itu, perencanaan khusus dimaksudkan untuk menyusun rancangan dari siklus per siklus. Oleh karenanya perencanaan khusus ini akan terjadi pengulangan atau perencanaan ulang (replanning). Hal-hal yang direncanakan di antaranya terkait dengan pendekatan pembelajaran, metode pembelajaran, teknik atau strategi pembelajaran, media dan materi pembelajaran, dan sebagainya. Perencanaan dalam hal ini kurang lebih hampir sama dengan apabila kita menyiapkan suatu kegiatan belajar-mengajar. 
Implementasi tindakan pada prinsipnya merupakan realisasi dari suatu tindakan yang sudah direncanakan sebelumnya. Strategi apa yang digunakan, materi apa yang diajarkan atau dibahas dan sebagainya. Pengamatan, observasi atau monitoring dapat dilakukan sendiri oleh peneliti atau kolaborator, yang memang diberi tugas untuk itu. Pada saat melakukan monitoring pengamat perlu mencatat semua peristiwa atau hal yang terjadi di kelas penelitian. Misalnya mengenai kinerja guru, situasi kelas, perilaku dan sikap siswa, penyajian atau pembahasan materi, penyerapan siswa terhadap materi yang diajarkan, dan sebagainya. Pada prinsipnya yang dimaksud dengan istilah refleksi ialah upaya evaluasi yang dilakukan oleh para kolaborator atau partisipan yang terkait dengan suatu PTK yang dilaksanakan. Refleksi ini dilakukan dengan kolaboratif, yaitu adanya diskusi terhadap berbagai masalah yang terjadi di kelas penelitian. Dengan demikian refleksi dapat ditentukan sesudah adanya implementasi tindakan dan hasil observasi. Berdasarkan refleksi ini pula suatu perbaikan tindakan (replanning) selanjutnya ditentukan. Laporan hasil penelitian PTK seperti halnya jenis penelitian yang lain, yaitu disusun sesudah kerja penelitian di lapangan berakhir.

Sebenarnya, PTK lebih bersifat individual. Artinya bahwa tujuan utama PTK adalah self-improvement melalui self-evaluation dan self-reflection, yang pada akhirnya bermuara pada peningkatan mutu proses dan hasil belajar siswa. Dengan demikian hasil pelaksanan PTK berupa terjadinya inovasi pembelajaran akan dilaporkan kepada diri si peneliti (guru sendiri). Guru perlu mengarsipkan langkah-langkah dan teknik pembelajaran yang dikembangkan melalui aktifitas PTK demi perbaikan proses pembelajaran yang dia lakukan di masa yang akan datang. Namun demikian, hasi PTK yang dilaksanakan tidak tertutup kemungkinan untuk diikuti oleh guru lain atau teman sejawat. Oleh karena itu guna melengkapi predikat guru sebagai ilmuwan sejati, guru perlu juga menuliskan pengalaman melaksanakan PTK tersebut ke dalam suatu karya tulis ilmiah. Dengan melaporkan hasil PTK tersebut kepada masyarakat (teman sejawat, pemerhati/pengamat pendidikan, dan para pakar pendidikan lainnya) guru akan memperoleh nilai tambah yaitu suatu bentuk pertanggungjawaban dan kebanggaan akademis/ilmiah sebagai seorang ilmuwan. Hasil kerja guru akan merupakan amal jariah yang sangat membantu teman sejawatnya dan siswa secara khusus. Melalui laporan kepada masyarakat, PTK yang pada awalnya dilaksanakan dalam skala kecil yaitu di ruang kelas, akan memberi sumbangsih yang cukup signifikan terhadap peningkatan mutu, proses, dan hasil belajar siswa. 
Terdapat beberapa Model Penelitian Tindakan Kelas. Diantaranya; Model Kurt Lewin. Model Kurt Lewin menjadi acuan pokok atau dasar dari adanya berbagai model penelitian tindakan yang lain, khususnya PTK. Dikatakan demikian, karena dialah yang pertama kali memperkenalkan Action Research atau penelitian tindakan. Konsep pokok penelitian tindakan Model Kurt Lewin terdiri dari empat komponen, yaitu ; a) perencanaan (planning), b) tindakan (acting), c) pengamatan (observing), dan d) refleksi (reflecting) (Rochiati, 2008: 63).

Selanjutnya, Model Spiral Stephen Kemmis dan Mc Taggart. Model Kemmis \& McTaggart merupakan pengembangan dari konsep dasar yang diperkenalkan oleh Kurt Lewin sebagaimana yang diutarakan di atas. Hanya saja, komponen acting (tindakan) dengan observing (pengamatan) dijadikan sebagai satu kesatuan. Disatukannya kedua komponen tersebut disebabkan oleh adanya kenyataan bahwa antara implementasi acting dan observing merupakan dua kegiatan yang tidak terpisahkan (Rochiati W, 2008: 66). Maksudnya, kedua kegiatan haruslah dilakukan dalam satu kesatuan waktu, begitu berlangsungnya suatu tindakan begitu pula observasi juga harus dilaksanakan. Untuk lebih tepatnya, berikut ini dikemukakan bentuk designnya.

Apabila dicermati, model yang dikemukakan oleh Kemmis \& McTaggart pada hakekatnya berupa perangkat-perangkat atau untaian-untaian dengan satu perangkat terdiri dari empat komponen, yaitu: perencanaan, tindakan, pengamatan dan refleksi. Keempat komponen yang berupa untaian tersebut dipandang sebagai satu siklus. Oleh karena itu, pengertian siklus pada kesempatan ini adalah suatu putaran kegiatan yang terdiri dari perencanaan, tindakan, pengamatan dan refleksi. Pada gambar di atas, tampak bahwa di dalamnya terdiri dari dua perangkat komponen yang dapat dikatakan sebagai dua siklus. Untuk pelaksanaan sesungguhnya, jumlah siklus sangat bergantung kepada permasalahan yang perlu diselesaikan.

Ada lagi Model Elliot. Elliot adalah seorang pendukung gerakan "guru sebagai peneliti". Ia mengembangkan model penelitian tindakan kelas yang telah dikembangkan oleh Kemmis. Namun, skema langkah-langkahnya lebih rinci dan berpeluang untuk lebih mudah diubah sehingga sebenarnya dia telah membuat suatu diagram yang lebih baik (Rochiati, 2008: 64),

\section{HASIL DAN PEMBAHASAN}

Masyarakat Kegiatan peningkatan profesionalitas guru dalam menghasilkan karya pengembangan profesi guru melalui pelatihan penulisan proposal penelitian tindakan kelas bagi guru mapel SMPIT Assalamah Ungaran 
dilaksanakan pada tanggal 31 Agustus 2015. Kegiatan pelatihan berjalan dengan lancar dihadiri oleh 30 peserta dari 4 undangan. Peserta pelatihan terlihat antusias dengan materi pelatihan yang diberikan. Hal ini terlihat dari awal hingga akhir acara, semua peserta mengikuti dengan baik. Materi mengenai konsep pengembangan karya profesi, arti penting pengembangan karya profesi dan peningkatan kualitas maupun kuantitas karya pengembangan karya profesi dalam bentuk proposal penelitian tindakan kelas. Pada hari tersebut juga peserta pengabdian melakukan workshop peningkatan pengembangan karya profesi guru. Guru-guru peserta pengabdian mengidentifkasi permasalahan yang layak diangkat untuk menjadi judul penelitian. Bagi guru yang telah melasanakan penelitian tindakan kelas, kegiatan yang dilakukan adalah menyusun proposal penelitian.

Masalah yang diangkat dalam proposal tersebut merupakan hasil kajian bidang studi. Hasil yang dicapai dalam kegiatan ini adalah karya judul dari kajian bidang studi. Hasil proposal yang telah disusun oleh guru dikumpulkan, diberi masukan dan selanjutnya diperbaiki lagi. Selama proses penulisan dilakukan tanya jawab dan diskusi antara peserta dan pengabdi untuk meningkatkan pemahaman sehingga akan memperleh hasil yang diinginkan.

Berdasarkan hasil kegiatan dapat diidentifkasi mengenai tingkat pemahaman peserta pengabdian adalah bahwa 70\% peserta pengabdian memahami konsep pengembangan karya profesi, arti penting pengembangan karya profesi dan arti penting peningkatan kualitas dan kuantitas pengembangan karya berbentuk proposal penelitian tindakan kelas dan artikel ilmiah baik bidang bahasa maupun pendidikan. Hasil yang terkumpul adalah sebanyak 6 judul proposal penelitian tindakan kelas.

Kegiatan pengabdian pelatihan pengembangan karya profesi yang berbentuk penlisan proposal penelitian tindakan kelas di segala bidang maupun pendidikan bagi guru mapel untuk meningkatkan profesionalitas guru dapat berjalan dengan lancar. Pelatihan penulisan proposal penelitian tindakan kelas memang nyata-nyata dibutuhkan bagi guru-guru mapel SMPIT Assalamah Ungaran. Kebanyakan peserta mengeluhkan kurangnya pengetahuan dan pemahaman akan karya pengembangan profesi dan arti pentingnya untuk meningkatkan profesionalitas mereka sebagai guru. Guruguru menyadari sepenuhnya bahwa karya ilmiah penting bagi mereka sebagai bentuk perwujudan pertanggungjawaban guru. Guru bertanggungjawab atas kegiatan pembelajaran yang dilaksanakannya sehingga mereka harus menjaga kualitas pembelajarannya. 
Untuk itu diperlukan penelitian tindakan yang dapat meningkatkan kualitas pembelajaran dengan menerapkan model pembelajaran yang inovatif. Hasil penelitian tidak akan banyak bermanfaat bagi orang lain kecuali ditulis dalam bentuk laporan penelitian tindakan kelas. Oleh karena itu guru merasakan banyak manfaat yang diperoleh dari pelatihan ini untuk meningkatkan kemampuannya dalam menulis proposal penelitian tindakan kelas. Guru hendaknya juga bertanggungjawab atas pengembangan ilmunya. Agar ilmu yang diembannya dapat dikembangkan dan tidak tertinggal, guru seyogyanya melakukan kajian keilmuan yang menjadi bidangnya, dalam hal ini bidang akuntansi. Agar kajian yang dilakukannya bermanfaat bagi orang banyak/ guru lain.

Kegiatan pelatihan ini dapat berjalan dengan lancar. Hal ini disebabkan adanya faktor yang mendukung berjalannya kegitan pengabdian. Hal-ha1 yang mendukung berjalannya kegiatan pengabdian ini dapat diidentifkasi diantaranya antusisme para peserta pelatihan. Faktor yang mendukung kegiatan adalah antusiasme peserta untuk memahami konsep pengembangan karya profesi, arti penting karya pengembangan profesi, pentingnya peningkatan kualitas dan kuantitas karya profesi serta kemauan dari peserta pengabdian untuk menulis. Antusisme dibuktikan dengan banyaknya pertanyaan yang muncul ketika pelaksanaan diskusi kelompok, pengerjaan tugas yaitu penulisan proposal penelitian tindakan kelas serta tidak adanya peserta yang membolos selama pelatihan.

Lancarnya pelaksanaan kegiatan pengabdian bukan berarti tanpa hambatan. Selama pengabdian ada beberapa hal yang diidentifkasi sebagai faktor penghambat kegiatan. Pengabdian diantaranya adalah rendahnya kemauan menulis bagi sebagian peserta pelatihan.

Faktor yang menghambat jalannya pengabdian yaitu bahwa menulis merupakan kegiatan yang tidak hanya membutuhkan kemampuan akan tetapi juga membutuhkan kemauan. Banyak guru yang mempunyai kemampuan untuk menulis akan tetapi belum mempunyai kemauan untuk menulis. Hal ini disebabkan kurangnya pemahaman mengenai pentingnya menulis untuk meningkatkan profesionalitas serta rendahnya motivasi untuk menulis.

\section{KESIMPULAN}

Kegiatan pelatihan pengembangan karya profesi yang berbentuk penulisan hasil laporan penelitian tindakan kelas maupun artikel ilmiah baik bidang 
akuntansi maupun pendidikan bagi guru akuntansi untuk meningkatkan profesionalitas guru dapatberjalan dengan lancar. Hampir semua peserta antusias dan merasakan manfaat pelatihan. Pelaksanaan pengabdian untuk guru-guru semua mapel SMPIT Assalamah Ungaran dapat disimpulkan berhasil sampai tahap pelatihan penulisan proposal penelitian tindakan kelas. Keberhasilan ini ditunjukkan antara lain oleh adanya kesesuaian materi dengan kebutuhan guru-guru semua mapel SMPIT Assalamah Ungaran. Adanya respon yang positif dari peserta mengingat kegiatan pengabdian merupakan kebutuhan guru dalam rangka peningkatan profesionalitasnya. Sebagianbesar $(70 \%)$ peserta telah memahami konsep pengembangan karya profesi, arti pentingkarya pengembangan profesi, pentingnya peningkatan kualitas dan kuantitas karyapengembangan profesi dalam bentuk penulisan proposal penelitian tindakan kelas dalam bidang bahasa Jepang dan pendidikan serta mampu mengembangkan menjadi sebanyak 6 judul.[]

\section{DAFTAR PUSTAKA}

Aqib, Zainal. 2009, Penelitian Tindakan Kelas. Bandung : Yrama Widya. Arikunto, Suharsimi, dkk., 2011, Penelitian Tindakan Kelas. Jakarta: Bumi Aksara.

As'adie, Basuki, 2009, Desain Pembelajaran Berbasis Penelitian Tindakan Kelas. Ponorogo: STAIN Ponorogo Press.

Bahri, Aliem. 2012, "Penelitian Tindakan Kelas". Makassar : Universitas Muhammadiyah Makassar.

Daryanto, 2011, Penelitian Tindakan Kelas dan Penelitian Tindakan Sekolah

Beserta Contoh- Contohnya, Yogyakarta : Gava Media.

Emzir, 2011, Metodologi Penelitian Pendidikan Kuantitatif dan Kualitatif, Jakarta: Raja Grafindo.

Kunandar, 2008, Langkah Mudah Penelitian Tindakan Kelas Sebagai

Pengembangan Profesi Guru, Jakarta: PT Raja Grafindo Persada.

Mulyasa, 2009 , Praktik Penelitian Tindakan Kelas, Bandung: PT Remaja Rosdakarya.

Sanjaya, Wina, 2011, Penelitian Tindakan Kelas, Jakarta : Kencana Prenada Media Group. 
Sukardi, 2011, Metodologi Penelitian Pendidikan, Jakarta : PT Bumi Aksara. Sukidin, dkk., 2010, Manajemen Penelitian Tindakan Kelas, Jakarta: Insan

Cendekia. Suyadi, 2012, Buku Panduan Guru Profesional Penelitian Tindakan Kelas (PTK) dan Penelitian Tindakan Sekolah, Yogyakarta : Andi. Suyadi, 2012, Panduan Penelitian Tindakan Kelas, Yogyakarta : Diva Press.

Syaodih, Nana, 2009, Metode Penelitian Pendidikan. Bandung: PT. Remaja Rosda Karya.

Tahir, Muh., 2012, Pengantar Metodologi Penelitian Pendidikan, Makassar : Universitas Muhammadiyah Makassar.

Wardhani, Igak.2007.’Penelitian Tindakan Kelas”.Jakarta:Universitas Terbuka. 
